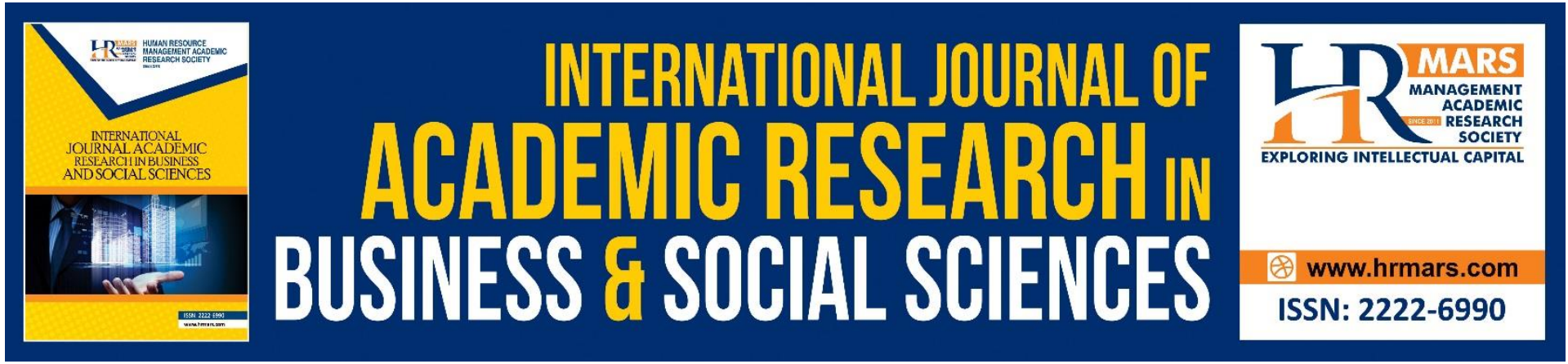

\title{
Systematic Literature Review on the Relationship between Religion and Business Success
}

\section{Awang Moslem Awang Annuar, Jati Kasuma Ali}

To Link this Article: http://dx.doi.org/10.6007/IJARBSS/v11-i7/10194

DOI:10.6007/IJARBSS/v11-i7/10194

Received: 19 May 2021, Revised: 23 June 2021, Accepted: 10 July 2021

Published Online: 28 July 2021

In-Text Citation: (Annuar \& Ali, 2021)

To Cite this Article: Annuar, A. M. A., \& Ali, J. K. (2021). Systematic Literature Review on the Relationship between Religion and Business Success. International Journal of Academic Research in Business and Social Sciences, 11(7), 529-546.

\section{Copyright: @ 2021 The Author(s)}

Published by Human Resource Management Academic Research Society (www.hrmars.com)

This article is published under the Creative Commons Attribution (CC BY 4.0) license. Anyone may reproduce, distribute, translate and create derivative works of this article (for both commercial and non-commercial purposes), subject to full attribution to the original publication and authors. The full terms of this license may be seen at: http://creativecommons.org/licences/by/4.0/legalcode

Vol. 11, No. 7, 2021, Pg. 529 - 546

Full Terms \& Conditions of access and use can be found at http://hrmars.com/index.php/pages/detail/publication-ethics 


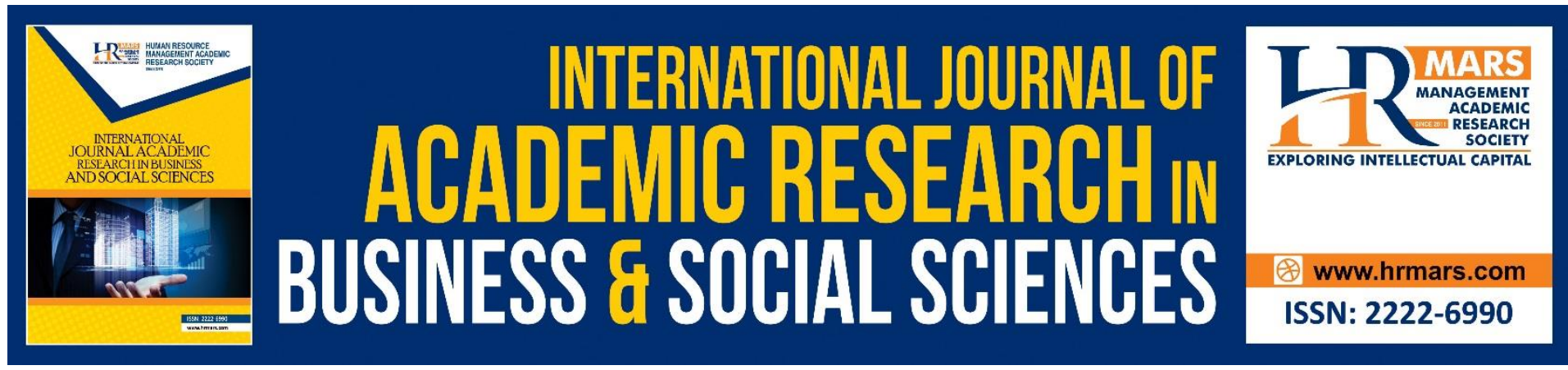

\title{
Systematic Literature Review on the Relationship between Religion and Business Success
}

\author{
Awang Moslem Awang Annuar \\ PhD Candidate, Universiti Teknologi MARA Shah Alam Malaysia \\ Email: azniaga@gmail.com \\ Dr. Jati Kasuma Ali
}

Associate Professor, Faculty of Business and Management, Universiti Teknologi MARA Kota

Samarahan Malaysia

Email: jatikasuma@hotmail.com

\begin{abstract}
The discussions on the relationship between religion and entrepreneurship have been well established since 1930. However the majority of literature reviews in this area are not systematic therefore this article will attempt to conduct a systematic literature review in this area more specifically on the relationship between religion and business success. This study is guided by adapting RepOrting standards for Systematic Evidence Syntheses (ROSES) review protocol. Based on thematic analysis, this study has identified 4 themes which are definitions and goals, roles and support, homophily, and guide and tools. This study offered several significant contributions for practical purposes and body of knowledge on this subject matter, namely the definition and goal of business entity in religious perspective is different than conventional business setup, the code of conduct of religiously inclined entrepreneurs are governed by their religions and cultures, cultures supported by religions can improve the success rate of entrepreneurs, homophily can be a universal bonding factors among entrepreneurs in their respective community and religion, and finally religious institutions can play important roles to help entrepreneurs and community to succeed.
\end{abstract}

Keywords: Religion, Business Success, Business Performance, Business Growth, Business Development

\section{Introduction}

In 1930s Max Weber started the discussions on the relationship between business and entrepreneurship in which he explained that religion impacted people's financial conduct among Protestant (Rehan et al., 2019), and whatever things that they do as business people (Audretsch et al., 2013; Nikolova \& Simroth, 2015).

According to Weber (1930), prior to the Protestant Reformation, most Christians who pursued religious lifer prefer ascetic lifestyle. However after the reformation, Calvinism which is 
another form of Christian Protestant encouraged different attitude towards working. They believed in pre-destination whereby only the chosen ones will go to heaven, and they were afraid that they will not be among the chosen ones. Therefore they were looking for ways or signs that they have been saved and among the chosen ones, and one way to do this is to contribute to their work by contributing to their community, thus playing an important role in the growth of capitalism in Northern Europe.

In conventional business, success is defined through market performance (Kozielski, 2019), sales growth (Cesinger et al., 2018), business age, turnover, staff numbers, and rate of growth (Fisher et al., 2018), organization's performance, relationships in the workplace, personal fulfilment, impact on community, and individual financial rewards (Angel et al., 2018), business financial and overall performance indicators (Carmona-Márquez et al., 2014) both financial and personal success (Dijkhuizen et al., 2016), financial, profitability, turnover and percentage success based on entrepreneur's own evaluation (Bernoster et al., 2020), operating without financial distress (Purves et al., 2015), entrepreneur's feelings of personal accomplishment (Zampetakis et al., 2017), sales, growth and profit (Anna et al., 2000; Honig, 1998; Sriram \& Mersha, 2017).

However the goal of business entity in religious perspective is different than conventional business setup, for example when it comes to business success Muslim entrepreneurs have different priorities, their main concern is the means to achieve success, then the result (Adewale, 2016; Ambrose et al., 2016; Amogechukwu, 2017; Issoufou, 2019; Mose \& Keino, 2017). As for Christians and Amish entrepreneurs success is based on survival and sustainability and the ultimate responsibility and devotion is towards the institution and community and not the business itself. The whole life should be spent in the service of God (Kininmonth, 2016; Kleymann \& Malloch, 2010; Kraybill \& Nolt, 2011)

\section{Identifying the Gap}

Even though there are studies conducted on religions and business success, not many are done using systematic review. This is due to the fact that entrepreneurship it is still comparatively a young discipline (Ferreira et al., 2019; Kraus et al., 2020). Entrepreneurship has emerged as a topic of growing interest among management scholars and social scientists since the 1980s. It has grown in legitimacy, particularly in business schools (Wadhwani \& Jones, 2006).

One of the ways to review existing literature in a more systematic approach is through systematic literature review (Mohamed Shaffril, Ahmad, et al., 2020). It is a process of classifying, selecting and critically appraising previous studies to answer a formulated question (Dewey and Drahota, 2006). This paper will attempt to contribute to the existing body of knowledge by developing a systematic literature review on the relationship between religion and business success.

Systematic literature review is a transparent and an organised process in which researcher/s is/are using several databases to conduct his/her research and this similar process can be reproduced and replicated by other researchers. It enables researchers to answer a defined question through a rigorous search strategy (Xiao \& Watson, 2019). 
In a systematic review paper, it will detail out the processes of conducting and producing the end material such as the reporting standard used, databases and keywords used, articles selection processes, quality appraisal and discussions. Theses systematic processes will enable other researchers to reproduce the investigation, and to confirm the analysis or study the generality.

This systematic review is guided by the central research question, which is "What is/are the relationship/s between religion and business success?" This study aims to gain more understanding on what the relationship/s between and business success is/are and how it affects or can affect business success of entrepreneurs.

This study offers several benefits to the practical aspects business success and to the body of knowledge. Through the understanding of the relationship between religion and business success, interested parties such as entrepreneurs can apply certain religious principles in their business that will affect their business success, whereas organizations or institutions such as government agencies that deal with entrepreneurs can include related religious values and/or principles that affect business success in their training programs and inside whatever services they provide to entrepreneurs. As for other researchers, this study can direct them onto specific or related religious principles and/or values that they can focus on in their studies.

\section{Methodology}

\section{The Review Protocol - RepOrting standards for Systematic Evidence Syntheses (ROSES)}

The study was guided by RepOrting standards for Systematic Evidence Syntheses in short ROSES review protocol see Figure 1 . This review protocol is designed specifically for systematic review and maps for environment management field (Haddaway et al., 2018) however it can be adapted to other fields of research. One of the main objectives of using ROSES review protocol in a systematic literature review is to ensure that the researchers provide accurate and relevant information with the right level of detail.

RepOrting standards for Systematic Evidence Syntheses review protocol started with the authors formulating the appropriate research questions for the review. Next, the authors will explain on their systematic searching strategy which will go through the following three main processes:

a. Identification,

b. Screening that consists of inclusion and exclusion criteria and

c. Eligibility of the resources (articles) for the review

Then the next step in the ROSES protocol is the appraisal of quality on the selected articles. Here, there authors will explain the strategy that they use to ensure that the articles to be reviewed are of a high-quality article. Finally, the last stage of ROSES review protocol is the explanation by the authors on how they abstract the data for the review and how the abstracted data will be analyzed and validated.

\section{Formulation of Research Question}

In this first phase, it is necessary to come up with a concise and clear research question to drive the entire systematic review methodology. As the objective of this article is to look at 
the relationship between any religion with business success, the following research question has been formulated - What is the relationship between religion and business success?

\section{Systematic Searching Strategies}

In order to ensure that the data use for this systematic literature review are relevant and suitable for this study, systematic searching strategies require researchers to go through these three main processes which are identification, screening with inclusion and exclusion criteria, and finally the eligibility of the resources.

\section{Identification}

This first step of systematic searching strategies is identification. It is a process to search for any related terms, synonym, and variation for the main keywords for the study, which are religion and business success. The aim of identification is to give more options and alternatives for the selected databases to search for more related and relevant articles for the review.

The keywords used for this systematic literature review paper are chosen based on the research question as recommended by Okoli (2015), and the identification process relied upon keywords used by past studies, online thesaurus, keywords suggested by Scopus, keywords suggested by Web of Science, and keywords suggested by experts.

The review relied on two main journal databases - Scopus and Web of Science (WoS). WoS is a robust database consisting of more than 33,000 journals with coverage of over 256 disciplines including subjects related to this study. It includes over 100 years of comprehensive back file and citation data, established by Clarivate Analytics. Whereas Scopus is the second database used in the review. It is one of the largest abstracts and citation databases of peer-reviewed literature with over 22,800 journals from 5000 publishers worldwide. Scopus consists of diverse subject areas such business, management, social science, technology, medicine arts and humanities, and science.

The authors managed to grow and vary the existing keywords and developed full search string on the two main databases namely Scopus and Web of Science by using various searching techniques such as phrase searching, Boolean operator, wild card, truncation, and field code functions.

Scopus and Web of Science databases are chosen as the databases in a systematic literature review because of several positive factors that they provide such as vast resources and comprehensive collections of materials for scientific and systematic research with indexing of more than 5000 publishers, advance searching functions, they control the quality of articles and they have multidisciplinary focus, including business and entrepreneurship related studies (Gusenbauer, 2019; Martín-Martín et al., 2018). From these two databases (Scopus and Web of Science) the authors managed to obtain 265 related articles (199 articles from SCOPUS and 99 articles from Web of Science) using the following search strings in Table 1 below. 
Table 1. Search Strings for SCOPUS and Web of Science databases

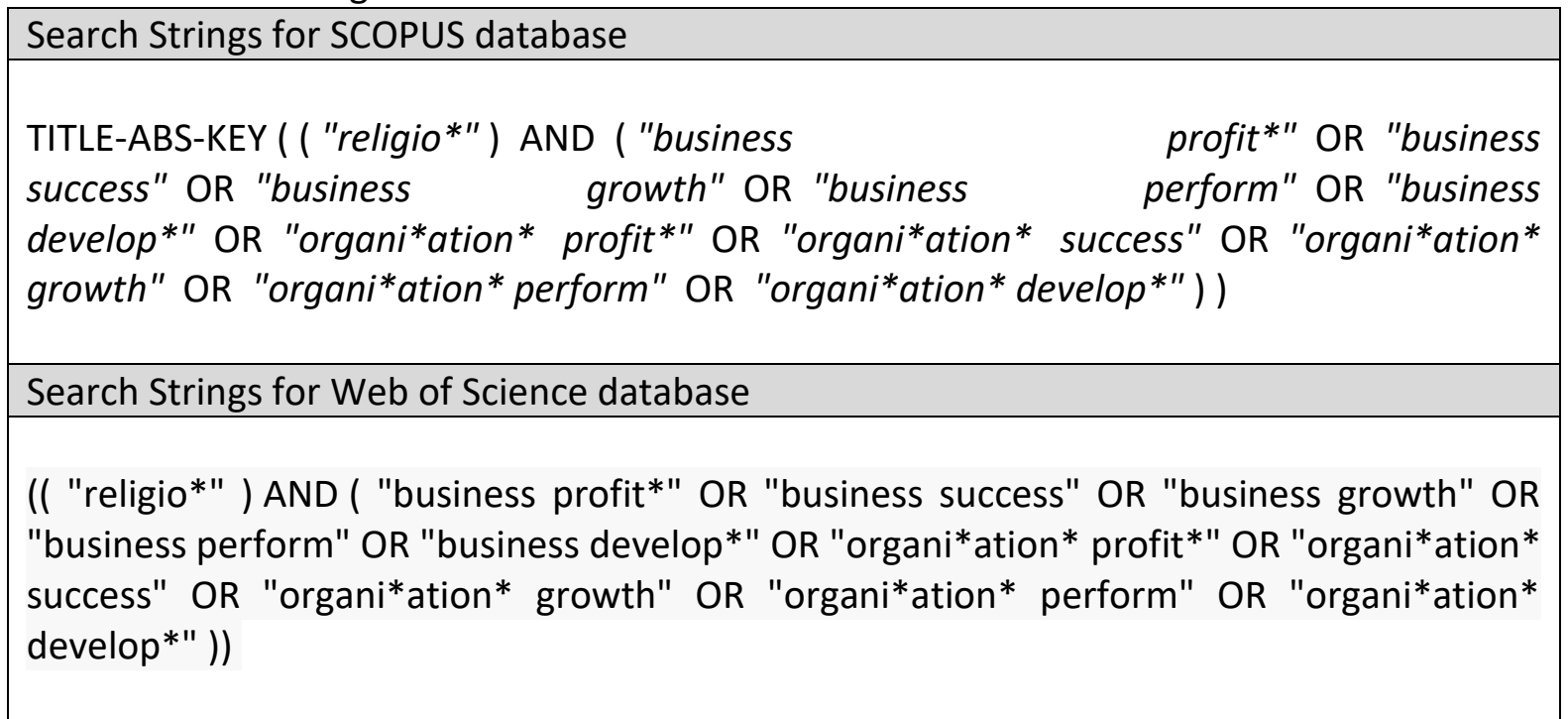

\section{Screening}

This study screened all 265 articles related using the criteria set in this study based on the research question for this systematic literature review. Okoli, (2015) suggested that researchers should determine range of period that they able to review, because it is almost impossible for the researchers to review all the existing published articles, thus specific timeframe between 2010 to 2020 is used as one of the inclusion criteria for this study.

Other inclusion criteria are, only publications in English are accepted, the related publications should only be in the fields of business, economic and social science, and only article, review, editorial and conference paper are selected as shown in Table 2 below for both SCOPUS and Web of Science databases. 
Table 2. Search strings with inclusion and exclusion criteria

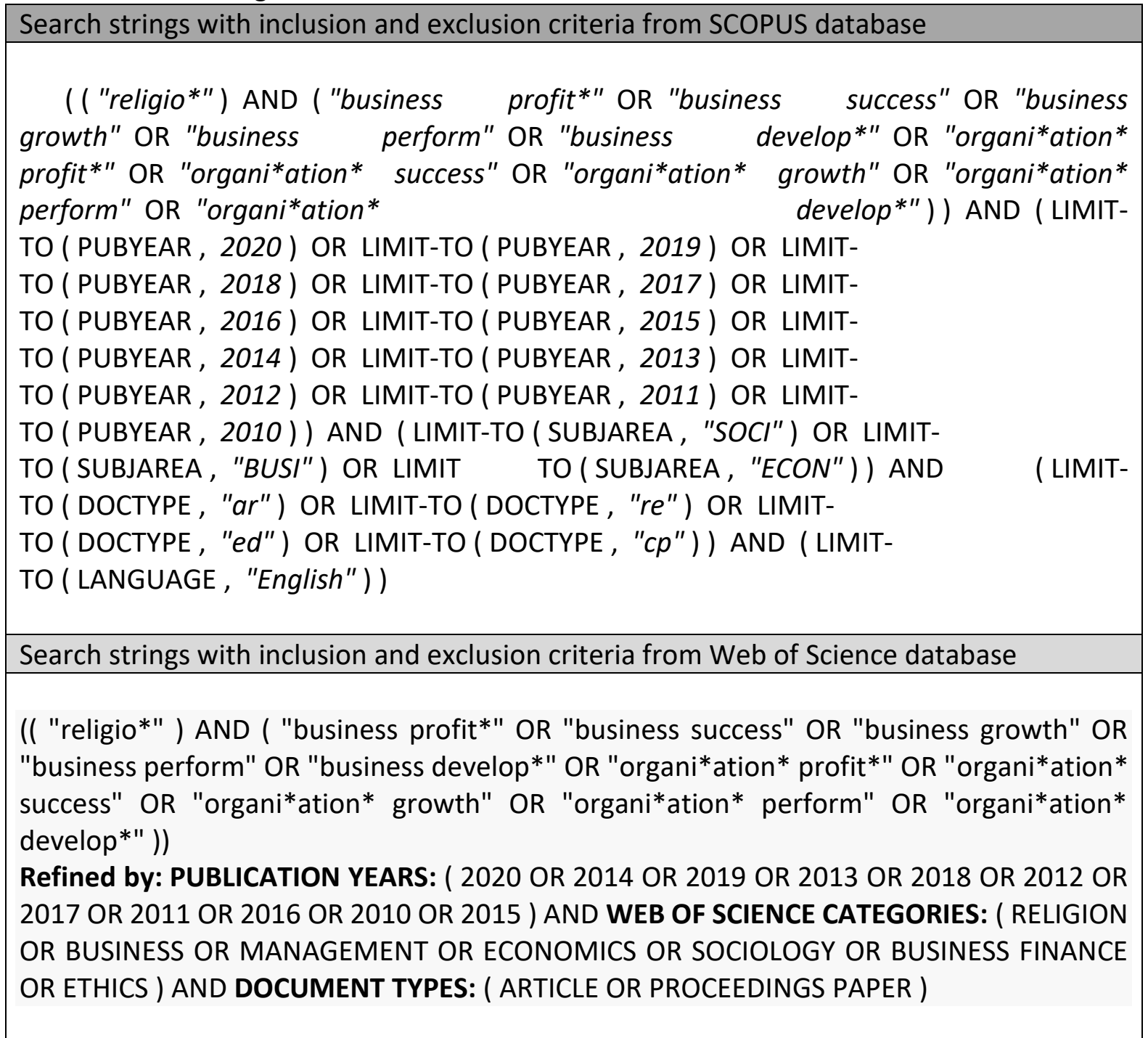

Out of 108 articles only 46 records are related to the study, in which 9 records are duplicated articles, and 2 articles are inaccessible. This brings to only 35 articles will be selected to go to the next stage of this systematic literature review, that is eligibility process.

\section{Eligibility}

Eligibility is the process in which the authors manually analysed the selected articles to ensure that all the remaining articles meet all the criteria set by them for the purpose of answering the research question, by going through the title and abstract of the articles. Out of 35 articles 17 full-text records were excluded due to focus on other areas such as stress, culture, shariah, Islamic products, human resource, general leadership and consumerism. This process resulted in 18 articles ready for quality appraisal process.

\section{Quality Appraisal}

In order to ensure that the quality of the articles can fulfil the objectives of this study by answering the research question, the remaining 18 articles were analysed by the authors. According to Mohamed Shaffril, Samsuddin, et al., (2020) authors can rank the selected articles, whereas Petticrew \& Roberts, (2006) suggested that experts should rank the 
remaining articles into three quality categories namely high, moderate, and only articles categorised as high and moderate should be reviewed.

In order to determine the rank of the quality the authors focused on the methodology of the articles, the relatedness of the articles to the research question, and only articles categorised as moderate and high level by both authors will be included in the review.

Both authors discussed any disagreement on the quality level of the articles before deciding on whether to include of exclude the articles for the review. This process categorised 11 articles as high and 7 articles as moderate quality. Therefore, all of the remaining 18 articles were eligible for the review.

\section{Data Abstraction and Analysis}

In order to obtain systematic findings from various research paper with diverse research designs such as qualitative, quantitative and mix-methods with integrative data, integrative review method is required. The best way to do this is by using qualitative or mixed-method techniques because it enables the researcher to analyse and synthesize the paper using iterative comparisons across the primary data sources (Whittemore \& Knafl, 2005).

Based on the research question, data were abstracted from 18 articles that were selected during the quality appraisal stage in the ROSES reposting system. These 18 articles were analysed carefully by the authors especially focus is given more on the abstract, methodology, results and discussion of each paper.

Any abstracted that can answer the research question are placed in a table using thematic analysis technique. Flemming et al., (2018), posited that thematic analysis is considered to be the most appropriate technique to analyze and synthesize a mixed research design. Thematic technique is a process of combining similar data into specific group which is based on the theme of the collected information. From each theme the authors came up with sub-themes (if any) that represent the similar or related information or pattern within the abstracted data (Braun \& Clarke, 2006).

Generating the themes is the first step of a thematic analysis, in which the authors will identify themes or patterns in the abstracted data of all the reviewed articles. From this process the authors have identified four main themes. Before accepting all themes, the authors reexamined each one of them to check for their accuracy related to the research question. Then the authors moved to the next stage which is naming the themes as explained in Results section in this systematic literature review.

The finalized themes are presented in the InnoSTRE 2020 Special Edition, Physical and Online Conference (Hybrid Conference) on the $25^{\text {th }}$ and $26^{\text {th }}$ of November 2020 at Universiti Teknologi MARA, Samarahan Campus, Sarawak, Malaysia to get feedback form the experts and participants. After a thorough discussions and presentation all themes are accepted to answer the research question and meet the quality standard of the systematic literature review. 


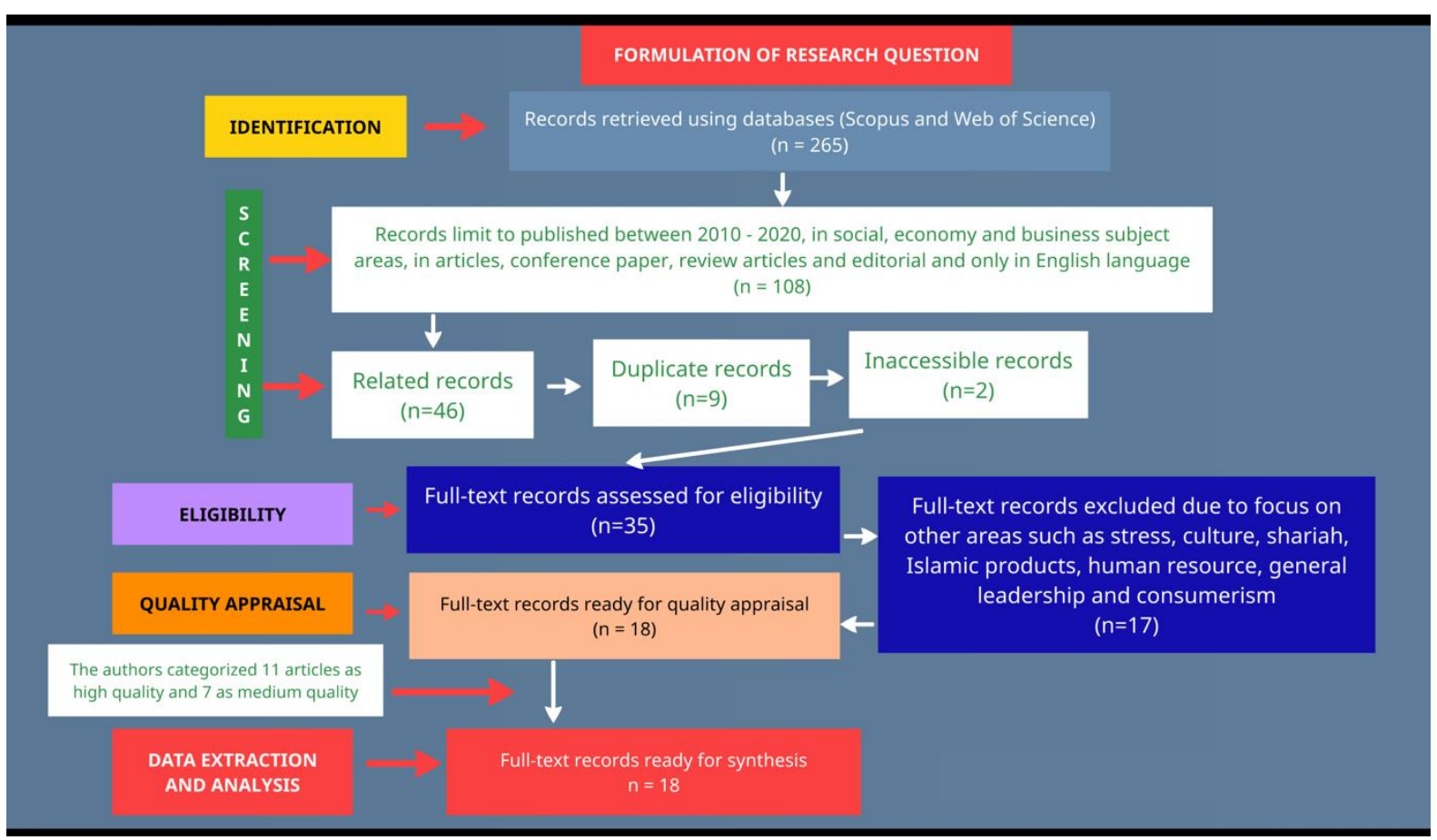

Figure 1 - Systematic Flow diagram (adapted from Mohamed Shaffril et al., (2019))

\section{Results}

\section{Background of Selected Articles}

Out of 18 articles were reviewed, four articles discussed within Islamic context looking at the work of Ibn Khaldun, entrepreneurs in Turkey, Pakistan and welfare protection of all stakeholders involved. Four articles discussed within Christianity, looking at Scottish and Korean entrepreneur, a Norwegian religious maverick, Hans Nielsen Hauge, and the Rule of Saint Benedict. Six articles discussed the relationship between religion and business success from different religions in Ethiopia, West-Africa, Malawi, Pakistan, USA and Ireland. One paper each, discussed within the context of Amish in North America, Confucianism in Hong Kong, Jewish ultra-Orthodox in Israel and spiritually-inspired creativity in business.

A thorough analysis of these 18 articles found 4 main themes by the authors that answer the research question. These 4 themes are:

1. Definition and Goals

2. Roles and Support

3. Guide and Tool, and

4. Homophily

\section{The Themes}

\section{Definition and Goals}

The key differences between conventional entrepreneurship and religious based entrepreneurship, or businesses in conventional context and businesses in religious context is in their ultimate goal and definition of success. 
Conventional businesses defined success by looking at financial and non-financial factors whereas, other than financial and non-financial factors, businesses in Islam and Christianity are looking at the responsibility to serve God as their number one priority.

Confirming to the work of Max Weber, Kininmonth (2016) affirmed that, Christians should spend their whole life to serve God, they should combine religion and their working lives, and whatever financial wealth that they have accumulated must be given away for the sake of serving God.

Even though some of the principles of the Rules of Saint Benedict (RSB) such as inverse delegation, fitting jobs around people, working on compatibility between people and their jobs, and a critical attitude towards organisational development are quite different from standard management practice, business organisations that run with the principles of RSB are more successful with high profitability and low employee turnover (Kleymann \& Malloch, 2010).

The influence of Amish religion has translated into a success rate of $90 \%$ among Amish businesses, which is higher than other American small businesses. For the Amish communities in North America, formal technological training, high levels of education, and an urban context are not crucial to determine entrepreneurial success. Rather, other religious practices such as to provide the unique practice of trusteeship to prevent financial collapse, reduce employee benefit and insurance costs can contribute to business success. (Kraybill \& Nolt, 2011)

To conclude, success is based on survival and sustainability and the ultimate responsibility and devotion towards the institution and community and not the business itself, and the whole life should be spent in the service of God (Kininmonth, 2016; Kleymann \& Malloch, 2010; Kraybill \& Nolt, 2011), and these factors are proven to be the catalyst of success for entrepreneurs that include religious practices and values in their business operations.

\section{Roles and Support}

Religion and spirituality provide help in difficult times for people, but also opportunities for improvement in their livelihoods and lifestyles. In both good times and bad, people seek the power of the God. In the face of uncertainty, be it environmental or broadly social, or in times of conflict, people may seek assurance and protection through faith, and it is a source of inspiration. (Swindell, 2019; Blot, 2012).

Entrepreneurial success stemmed from a unique combination of religious beliefs, an acute awareness of business opportunities. On top of that ancestor worship, a profoundly humancentered religiosity, religious beliefs, and socio-culture must be taken into consideration. (Dalgaard \& Supphellen, 2011; Zheng \& Wan, 2020)

Institutions played an important role in community development of the ethnic community. They assist and encourage the community regarding business opportunities, networking and information sharing. The community goes beyond structures and social links, and is based on sentiments such as trust, gratitude, courtesy, sympathy, and deeply shared common interests greatly benefited business development (Choi, 2010; Kleymann \& Malloch, 2010). 


\section{Guide and Tools}

According to Zsolnai \& Illes (2017), there are numerous evidences that showed instead of producing true well-being for the people, materialistic model of modern mainstream business actually undermines our well-being. Whereas, "Outmoded mental models have produced an intellectual bankruptcy: the bankruptcy of mainstream economic thought." (Scharmer \& Kaufer, 2013, p. 11)

Therefore different type of guide and tools are essential in order to help businesses to serve their stakeholders better thus perform better. Spirituality appears to be a precondition of creativity in good and caring management (Zsolnai \& Illes, 2017), whereas the welfare and protection of all stakeholders of organization can provide better financial gains and good reputation for long-term business performance (Abbasi et al., 2010).

Aside from a source of creativity and a guide for welfare and protection of stakeholders, religion is also a tool for conflict resolution, allocation of responsibilities, the management of organizational boundaries and interfaces with the outside world (Kleymann \& Malloch, 2010). As for the members of Amish community in North America, religious beliefs, long-standing customs, and church regulations known as Ordnung guide their enterprising activities. This has proven to be very effective to them in which their business success rate is $90 \%$ which is greater than other American small businesses (Kraybill \& Nolt, 2011)

\section{Homophily}

While there is empirical evidence that suggests that religion can induce homophily in the form of weak ties and thus facilitate business relationships. However, in religious communities in particular, social networks enable the existence of businesses, but do not contribute to their success. Emotional support is more important than financial and business management. (Kurt et al., 2020; Lo Turco \& Maggioni, 2018; Monnickendam-Givon et al., 2018; Richardson \& Rammal, 2018).

According to Kurt et al (2020) Muslim entrepreneurs who treat their business network as an extension of their spiritual practice will have the tendency to contribute more than they take out. They also pointed out that the existence of homophily definitely have a distinctive effect, but not entirely in business network setting.

In Islam, the concept of global Muslim umma provides a sense of kinship that is different from that of common ancestry, and with feelings of belonging to a larger Muslim community. A wide, stable and general set of principles of business practices can be obtained from Muslim religious norms (Mitra \& Basit, 2019).

Whereas for the micro-enterprise ultra-Orthodox Jewish entrepreneurs, strong personal relationship provides emotional support, social legitimacy and assistance in the operation and management of their daily activities. However, capitalizing on business network did not contribute to enterprise success which is contrary to the existing literature. In other words, in religious communities, social networks enable business existence, but do not contribute to their success." (Monnickendam-Givon et al., 2018) 
Religion, ethnicity, sex and marital status are the main attributes underlying homophily among informal entrepreneurs but not in term of education, occupation, income and age. Network homophily is very important at initial phase of establishing enterprise groups and once these entrepreneurs started their fully fledged operation, the core to their success depend on their cooperation with peoples of diverse socio-demographic characteristics (Kebede, 2017).

\section{Discussion}

The thematic analyses in this systematic review have identified four themes that explained the relationship between religion and business success, and in this section, their contributions to the body of knowledge of entrepreneurship systematic literature review and their applications will be discussed.

As explained in the first theme - Definition and Goals of conventional business and religious based businesses are different. Having clear definition of business success, and goals that are closely tie up to religion have several advantages over conventional business definition of success and goals.

For example the ability to serve God as the definition or part of the definition of business success will result in many positive outcomes, not just to entrepreneurs but to all stakeholders. Knowing that your day to day business operations will be rewarded by God will give you a piece of mind and knowing that every decision and action that you take will be monitored by God will make you be more aware of the negative consequences should you intent to do something that is against your religious teaching. This results in a win-win relationship between you and your stakeholders which include your employees, your boss, your supplier and your customers, just to name a few.

Even though serving God is the number one priority for religious entrepreneurs, financial and non-financial measurement of business are also part of business success, therefore they should not ignore these two components of business success. In other words, their approach on dealing with conventional financial and non-financial factor of a business success must be in line with the teaching of their religion and not the other way round.

Roles and support, as the second theme identified in this systematic review pointed out that religious institutions and communities are there to play their roles to support each other in spiritual, social and economic wellbeing.

The roles of house of worships such is mosque, churches, synagogue, Buddhist temple and the like should be more than a place for worship, but a place for every community to help themselves in all aspects of life like, economy, health, social, career and many more. Even though there are house of worships are playing their roles to support their community but more should be done so that all house of worships will become the catalyst for the success of their community.

For Muslims "... the mosque is actually meant by the Prophet Muhammad peace be upon him to be the community center of the Muslims to forge their brotherhood, to pray together, to 
help on another and to interact positively with the non-Muslim" as cited by Asif \& Utaberta, (2016, p. 6).

Religion can be the guide and tools to a business success. For example in Islam there is specific guide to do business transactions which are explained in Kitab Al-Buyu' or The Book of Transactions. This book is part of the collections of Sahih Muslim which are collections of authentic hadith of Prophet Muhammad peace be upon him, collected by Muslim scholar by the name of Muslim ibn al-Hajjaj, born in 817/18 CE in Iran.

Among others Kitab Al-Buyu' discusses about how business dealings should be based strictly on truth and justice. Prophet Muhammad peace be upon him disapproved, all transactions which involve any kind of injustice or one sided deal to the buyer or the seller. Business in Islam insists that the buyer and the seller, should be truly considerate and sympathetic towards each other. They should not take advantage of the simplicity or ignorance of the other, and many more. This comprehensive guide can be a great source and tool for entrepreneurs to achieve great success in their business venture.

As posited by Kleymann \& Malloch, (2010) aside from a source of creativity and a guide for welfare and protection of stakeholders, religion is also a tool for conflict resolution, allocation of responsibilities, the management of organizational boundaries and interfaces with the outside world.

The final theme identified in this systematic review is homophily. According to Kebede, (2017) homophily is to a likelihood of individuals to form relationship excessively with others like themselves. Even though religion can create homophily among its followers, this systematic review found out that homophily does not necessarily contribute to business success. This is due to the fact that the relationship between them are closely related withing specific boundaries only such ethnicity, sex and marital status but not in term of education, occupation, income and age. This is true especially among informal entrepreneurs.

Mistrust from previous experiences is also another contributing factors why the existence of homophily among entrepreneurs are just merely bonding based on social relationship and not business relationship.

Therefore extensive effort to learn more about the existence and the importance of homophily among certain groups of people especially religion based relationship must be carried out so that this homophily based business network will contribute to the business success of its participants significantly.

\section{Conclusion and Recommendations}

The role of religion in business is crucial because of its contributions to the stakeholders, which include seller, buyer, employer, employee, community and the government. As among the major contributors in a nation's economy, business should be a source prosperity and not disaster.

Over and over again, we heard of business and financial scandals like Enron, Lehman Brothers, $\mathrm{BP}$, WorldCom and $1 \mathrm{MDB}$, just to name a few that resulted in billions of dollars and hundreds 
of thousands of lives affected. These unfortunate events will never had happened if businesses align themselves with the true teaching of religion.

When our ultimate business goal is to please and serve the one true God, then the reset of our affairs will be taken care of. Our every move and decision will be done carefully, because we know that we are going to answer for every action that we do in this lifetime.

To future scholars, we recommend that they focus on conducting systematic literature review on the relationship between specific religion and business success. This is due to the fact that, not many studies are done on it, and entrepreneurship is still comparatively a young discipline (Ferreira et al., 2019; Kraus et al., 2020). Even though this paper found that there is a relationship between religion and business success, and religion can affect business performance but not entirely.

As a religion that is a way of life, Muslim entrepreneurs should be able to use Islam as the source of their business success, not partially but fully. Therefore future researchers especially who are interested in Islam, business and entrepreneurship, should carry out more research on this subject matter so that more findings can be obtained and the realization of using Islam as the source business success can be materialized.

\section{Contributions}

\section{Theoretical Contribution}

Even though in the western world, the concept of spirituality can be separated from religion and not interchangeable (Rassool, 2000; Zohar \& Marshal, 2004) future research should integrate Spiritual Intelligence Theory in their study of business ethics and good governance, as religion can influence business practices and outcome as presented in this systematic literature review.

\section{Contextual Contribution}

Business organizations can eliminate, prevent or at least minimise the massive losses from the scandals caused by the lack of religious consciousness, if they align themselves with true religious practices. Scandals such as with Enron, Lehman Brothers, BP, WorldCom and 1MDB, just to name a few that resulted in billions of dollars and hundreds of thousands of lives affected, could be prevented in the future if only the elements of religion are included in business practices and governance.

\section{References}

Abbasi, A. S., Rehman, K. U., \& Abbasi, S. H. (2010). Welfare and Protection Model for Organizational Management: The Islamic Perspective. African Journal of Business Management, 4(5), 739-747.

Adewale, A. A. (2016). Change, Customer Satisfaction and Competition: Issues from the Strategic Management Context. International Journal of Economics, Business and Management Studies, 3(04), 55-66. https://doi.org/10.20448/802.3.2.55.66

Ambrose, A. O., Etim, I. E., \& Enagu, F. M. (2016). The Role of Community Development Programmes in Poverty Aleviation in Nigeria: Lessons from Onelga, Rivers State, Nigeria. 1(1), 10-34. https://doi.org/10.20448/journal.801/2016.1.1/801.1.10.34

Amogechukwu, E. T. (2017). Extent of Head Teachers' Utilization of Innovative Sources of 
Funding Primary Schools in Enugu State of Nigeria. Journal of Education and E-Learning Research, 4(2), 41-45. https://doi.org/10.20448/journal.509.2017.42.41.45

Angel, P., Jenkins, A., \& Stephens, A. (2018). Understanding entrepreneurial success: A phenomenographic approach. International Small Business Journal: Researching Entrepreneurship, 36(6), 611-636. https://doi.org/10.1177/0266242618768662

Anna, A. L., Chandler, G. N., Jansen, E., \& Mero, N. P. (2000). Women business owners in traditional and non-traditional industries. Journal of Business Venturing, 15(3), 279-303. https://doi.org/10.1016/S0883-9026(98)00012-3

Asif, N., \& Utaberta, N. (2016). Masjid- The Spiritual and Physical Hub for Community Development. November, $119 . \quad$ https://www.academia.edu/30093777/Masjid__The_Spiritual_and_Physical_Hub_for_Community_Development

Audretsch, D. B., Bönte, W., \& Tamvada, J. P. (2013). Religion, social class, and entrepreneurial choice. Journal of Business Venturing, 28(6), 774-789.

https://doi.org/10.1016/j.jbusvent.2013.06.002

Bernoster, I., Mukerjee, J., \& Thurik, R. (2020). The role of affect in entrepreneurial orientation. Small Business Economics, 54(1), 235-256. https://doi.org/10.1007/s11187018-0116-3

Braun, V., \& Clarke, V. (2006). Using thematic analysis in psychology. Qualitative Research in Psychology, 3(2), 77-101. https://doi.org/10.1191/1478088706qp063oa

Carmona-Márquez, F. J., Leal-Millán, A. G., \& Vázquez-Sánchez, A. E. (2014). TQM and business success.

Cesinger, B., Gundolf, K., \& Géraudel, M. (2018). Growth intention and sales revenue growth in small business: The mediating effect of firm size growth. International Journal of Technology Management, 78(3), 163-181. https://doi.org/10.1504/IJTM.2018.095628

Choi, H. (2010). Religious institutions and ethnic entrepreneurship: The Korean ethnic church as a small business incubator. Economic Development Quarterly, 24(4), 372-383. https://doi.org/10.1177/0891242410375426

Dalgaard, B. R., \& Supphellen, M. (2011). Entrepreneurship in Norway's economic and religious nineteenth-century transformation. Scandinavian Economic History Review, 59(1), 48-66. https://doi.org/10.1080/03585522.2011.541123

Dijkhuizen, J., Veldhoven, M. van, \& Schalk, R. (2016). Four Types of Well-being among Entrepreneurs and Their Relationships with Business Performance. Journal of Entrepreneurship, 25(2), 184-210. https://doi.org/10.1177/0971355716650369

Emmons, R. A. (2000). Is Spirituality an Intelligence? Motivation, Cognition, and the Psychology of Ultimate Concern. The International Journal for the Psychology of Religion, 10(1), 3-26. https://doi.org/10.1207/S15327582IJPR1001

Ferreira, J. J. M., Fernandes, C. I., \& Kraus, S. (2019). Entrepreneurship research: mapping intellectual structures and research trends. Review of Managerial Science, 13(1), 181205. https://doi.org/10.1007/s11846-017-0242-3

Fisher, R., Merlot, E., \& Johnson, L. W. (2018). The obsessive and harmonious nature of entrepreneurial passion. International Journal of Entrepreneurial Behaviour and Research, 24(1), 22-40. https://doi.org/10.1108/IJEBR-01-2017-0011

Flemming, K., Booth, A., Garside, R., Tunçalp, Ö., \& Noyes, J. (2018). Qualitative evidence synthesis for complex interventions and guideline development: clarification of the purpose, designs and relevant methods. BMJ Global Health, 4(Suppl 1), e000882. https://doi.org/10.1136/bmjgh-2018-000882

Gusenbauer, M. (2019). Google Scholar to overshadow them all? Comparing the sizes of 12 
academic search engines and bibliographic databases. In Scientometrics (Vol. 118, Issue 1). Springer International Publishing. https://doi.org/10.1007/s11192-018-2958-5

Haddaway, N. R., Macura, B., Whaley, P., \& Pullin, A. S. (2018). ROSES Reporting standards for Systematic Evidence Syntheses: Pro forma, flow-diagram and descriptive summary of the plan and conduct of environmental systematic reviews and systematic maps. Environmental Evidence, 7(1), 4-11. https://doi.org/10.1186/s13750-018-0121-7

Honig, B. (1998). What determines success? Examining the human, financial, and social capital of Jamaican microentrepreneurs. Journal of Business Venturing, 13(5), 371-394. https://doi.org/10.1016/S0883-9026(97)00036-0

Issoufou, C. (2019). Creation of young entrepreneurs as resources of economic development and alleviation of poverty in muslim countries: An Islamic approach. Humanities and Social Sciences Reviews, 7(5), 1060-1064. https://doi.org/10.18510/hssr.2019.75141

Kebede, G. F. (2017). Exploring the Social Capital of the Urban Poor for Successful Microenterprise Development Programs in Ethiopia. Urban Forum, 28(3), 271-292. https://doi.org/10.1007/s12132-017-9305-4

Kininmonth, K. (2016). Weber's Protestant Work Ethic: a case study of Scottish entrepreneurs, the Coats Family of Paisley. Business History, 58(8), 1236-1261.

https://doi.org/10.1080/00076791.2016.1172569

Kleymann, B., \& Malloch, H. (2010). The rule of Saint Benedict and corporate management: employing the whole person. Journal of Global Responsibility, 1(2), 207-224. https://doi.org/10.1108/20412561011079362

Kozielski, R. (2019). Determinants of SMEs business success - emerging market perspective. International Journal of Organizational Analysis, 27(2), 322-336. https://doi.org/10.1108/IJOA-02-2018-1343

Kraus, S., Breier, M., \& Dasí-Rodríguez, S. (2020). The art of crafting a systematic literature review in entrepreneurship research Content courtesy of Springer Nature, terms of use apply . Rights reserved . Content courtesy of Springer Nature, terms of use apply . Rights reserved . International Entrepreneurship and Management Journal, 16, 1023-1042.

Kraybill, D. B., \& Nolt, S. M. (2011). Sources of enterprise success in Amish communities. Journal of Enterprising Communities: People and Places in the Global Economy, 5(2), 112130. https://doi.org/10.1108/17506201111131541

Kurt, Y., Sinkovics, N., Sinkovics, R. R., \& Yamin, M. (2020). The role of spirituality in Islamic business networks: The case of internationalizing Turkish SMEs. Journal of World Business, 55(1), 101034. https://doi.org/10.1016/j.jwb.2019.101034

Lo Turco, A., \& Maggioni, D. (2018). Effects of Islamic religiosity on bilateral trust in trade: The case of Turkish exports. Journal of Comparative Economics, 46(4), 947-965. https://doi.org/10.1016/j.jce.2018.02.001

Martín-Martín, A., Orduna-Malea, E., Thelwall, M., \& Delgado López-Cózar, E. (2018). Google Scholar, Web of Science, and Scopus: A systematic comparison of citations in 252 subject categories. Journal of Informetrics, 12(4), 1160-1177.

https://doi.org/10.1016/j.joi.2018.09.002

Mitra, J., \& Basit, A. (2019). Personal networks and growth aspirations: a case study of secondgeneration, Muslim, female entrepreneurs. Small Business Economics. https://doi.org/10.1007/s11187-019-00211-3

Shaffril, M. H. A., Ahmad, N., Samsuddin, S. F., Samah, A. A., \& Hamdan, M. E. (2020). Systematic literature review on adaptation towards climate change impacts among indigenous people in the Asia Pacific regions. Journal of Cleaner Production, 258, 120595. 
https://doi.org/10.1016/j.jclepro.2020.120595

Shaffril, M. H. A., Samah, A. A., Samsuddin, S. F., \& Ali, Z. (2019). Mirror-mirror on the wall, what climate change adaptation strategies are practiced by the Asian's fishermen of all? Journal of Cleaner Production, 232, 104-117.

https://doi.org/10.1016/j.jclepro.2019.05.262

Mohamed Shaffril, H. A., Samsuddin, S. F., \& Abu Samah, A. (2020). The ABC of systematic literature review: the basic methodological guidance for beginners. Quality and Quantity, 0123456789. https://doi.org/10.1007/s11135-020-01059-6

Monnickendam-Givon, Y., Schwartz, D., \& Gidron, B. (2018). The surprising lack of connection between social networks and the enterprise success of ultra-religious female microentrepreneurs. Journal of Enterprising Communities, 12(3), 395-415. https://doi.org/10.1108/JEC-05-2017-0031

Mose, N. G., \& Keino, I. J. (2017). Effect of Budget Defict on Private Investment in East African Community for the Period 1981-2015: A Panel Data Analysis. International Journal of Business, Economics and Management, 4(2), 26-37. https://doi.org/10.18488/journal.62.2017.42.26.37

Nikolova, E., \& Simroth, D. (2015). Religious diversity and entrepreneurship in transition: lessons for policymakers. IZA Journal of European Labor Studies, 4(1). https://doi.org/10.1186/s40174-014-0028-4

Okoli, C. (2015). A guide to conducting a standalone systematic literature review. Communications of the Association for Information Systems, 37(1), 879-910. https://doi.org/10.17705/1cais.03743

Petticrew, M., \& Roberts, H. (2006). M. Petticrew and H. Roberts. Systematic Reviews in the Social Sciences: A Practical Guide . Oxford: Blackwell 2006. 352 pp. ISBN 1405121106. f29.99. Counselling and Psychotherapy Research, 6(4), 304-305. https://doi.org/10.1080/14733140600986250

Purves, N., Niblock, S., \& Sloan, K. (2015). Are organizations destined to fail? Unit 07, 1-5.

Rassool, G. H. (2000). The crescent and Islam: Healing, nursing and the spiritual dimension. Some considerations towards an understanding of the Islamic perspectives on caring. Journal of Advanced Nursing, 32(6), 1476-1484. https://doi.org/10.1046/j.13652648.2000.01614.x

Rehan, F., Block, J. H., \& Fisch, C. (2019). Entrepreneurship in Islamic Communities: How Do Islamic Values and Islamic Practices Influence Entrepreneurship Intentions? SSRN Electronic Journal, June. https://doi.org/10.2139/ssrn.3405196

Richardson, C., \& Rammal, H. G. (2018). Religious belief and international business negotiations: Does faith influence negotiator behaviour? International Business Review, 27(2), 401-409. https://doi.org/10.1016/j.ibusrev.2017.09.007

Scharmer, O. C., \& Kaufer, K. (2013). Leading from the Emerging Future: From Ego-System to Eco-System Economies. In Leading from emerging future. https://books.google.com/books?id=XHWTyq6ivncC\&pgis=1

Sriram, V., \& Mersha, T. (2017). Entrepreneurial drivers and performance: An exploratory study of urban minority and women entrepreneurs. International Journal of Entrepreneurship and Small Business, 31(4), 514-533. https://doi.org/10.1504/IJESB.2017.085429

Swindell, K. (2019). Faith, Work, Farming and Business: The Role of the Spiritual in West African Livelihoods. Journal of Asian and African Studies, 54(6), 819-837. https://doi.org/10.1177/0021909619840754 
Wadhwani, R. D., \& Jones, G. (2006). Entrepreneurship and Business History : Renewing the Research Agenda. Harvard Business School Gjones@hbs.Edu, 51.

Whittemore, R., \& Knafl, K. (2005). The integrative review: updated methodology. Nursing Research, 9(1 SUPPL), 11-21. https://doi.org/10.1016/j.pmn.2007.11.006

Xiao, Y., \& Watson, M. (2019). Guidance on Conducting a Systematic Literature Review. Journal of Planning Education and Research, 39(1), 93-112. https://doi.org/10.1177/0739456X17723971

Zampetakis, L. A., Bakatsaki, M., Kafetsios, K., \& Moustakis, V. S. (2017). Examining the relationship among gender role orientation, future-oriented emotions and subjective entrepreneurial success. Research on Emotion in Organizations, 13, 157-173. https://doi.org/10.1108/S1746-979120170000013009

Zheng, V., \& Wan, P. san. (2020). Chinese culture and banyan-tree style family businesses: The enterprising family of Lo Ying-shek in Hong Kong. Business History, 0(0), 1-22. https://doi.org/10.1080/00076791.2020.1727448

Zohar, D., \& Marshal, I. (2004). Spiritual Capital Wealth We Can Live By. In Berrett-Koehler Publisher, Inc. https://doi.org/10.1017/CBO9781107415324.004

Zsolnai, L., \& Illes, K. (2017). Spiritually-inspired creativity in business. International Journal of Social Economics, 44(2), 195-205.

https://www.researchgate.net/publication/313661068_Spiritually_inspired_creativity_ in_business/citation/download 